\title{
Sexual dimorphism, diet, and notes on reproduction in Oxyrhopus trigeminus (Serpentes: Colubridae) in the semiarid Caatinga of northeastern Brazil
}

\author{
Rafael Damasceno Fernandes Coelho, ${ }^{1}$ Raul Fernandes Dantas Sales, ${ }^{2}$ and Leonardo Barros \\ Ribeiro $^{3}$ \\ ${ }^{1}$ Curso de Pós-graduação em Ciências Veterinárias no Semiárido, Universidade Federal do Vale do São Francisco, Campus \\ Ciências Agrárias. BR 407, Km 12, lote 543, Projeto de Irrigação Nilo Coelho s/n, C1, 56300-000, Petrolina, PE, Brazil. \\ ${ }^{2}$ Laboratório de Herpetologia, Departamento de Botânica e Zoologia, Centro de Biociências, Universidade Federal do Rio \\ Grande do Norte, Campus Universitário. Lagoa Nova, 59072-970, Natal, RN, Brazil. \\ ${ }^{3}$ Centro de Conservação e Manejo de Fauna da Caatinga (CEMAFAUNA), Universidade Federal do Vale do São Francisco. \\ Av. José de Sá Maniçoba s/n, Centro, 56304-917, Petrolina, PE, Brazil. E-mail: leonardo.ribeiro@univasf.edu.br.
}

\begin{abstract}
Sexual dimorphism, diet, and notes on reproduction in Oxyrhopus trigeminus (Serpentes: Colubridae) in the semiarid Caatinga of northeastern Brazil. Selected morphological characters, diet, and reproduction of the false-coral snake, Oxyrhopus trigeminus, from several localities in the Caatinga region of northeastern Brazil are described based on examination of preserved specimens. Sexual dimorphism is evident, with females attaining larger body sizes than males, but males have relatively larger heads and tails. A total of 25 prey items was identified in 23 of the 97 O. trigeminus examined; based on the orientation of the prey in the stomachs, all items were ingested headfirst. Lizards are the most frequent prey (96\%) of O. trigeminus, with the lizard Tropidurus hispidus being the most important prey species both in number and in volume; marsupials account for $4 \%$ of the diet. Juveniles have a narrower dietary niche width than adults, presumably because they have smaller mouths with a narrower gape. Females have a wider dietary niche than males, but there is a high niche overlap between the sexes; males and females do not differ in prey volumes. The analysis of the gonads showed that 10 females have 4-13 vitellogenic follicles (mean $7.8 \pm 2.8$ follicles), and 2 females have oviducal eggs, one with only one egg and the other with five eggs. The estimated minimum size at maturity for female O. trigeminus in the Caatinga is $400 \mathrm{~mm}$.
\end{abstract}

Keywords: feeding ecology, meristic data, Pseudoboini, reproductive condition, Tropical dry forest. 


\begin{abstract}
Resumo
Dimorfismo sexual, dieta e notas sobre a reprodução em Oxyrhopus trigeminus (Serpentes: Colubridae) na Caatinga semiárida do nordeste do Brasil. Caracteres morfológicos selecionados, dieta e reprodução da serpente falsa-coral, Oxyrhopus trigeminus, de várias localidades da região da Caatinga do nordeste do Brasil, são descritos com base no exame de espécimes preservados. O dimorfismo sexual é evidente, com as fêmeas atingindo maiores tamanhos corporais que os machos, mas os machos possuindo cabeças e caudas relativamente maiores. Um total de 25 itens alimentares foi identificado em 23 dos 97 espécimes de $O$. trigeminus; com base na orientação das presas no interior dos estômagos, todas foram ingeridas primeiramente pela cabeça. Lagartos são as presas mais frequentes de O. trigeminus (96\%), com o lagarto Tropidurus hispidus representando a espécie de presa mais importante tanto em número quanto em volume; marsupiais representam $4 \%$ da dieta. Os juvenis apresentam uma menor amplitude de nicho que os adultos, presumivelmente devido a limitações de tamanho da boca. As fêmeas têm uma maior amplitude de nicho que os machos, mas há uma alta sobreposição de nicho entre os sexos; machos e fêmeas não diferem no volume das presas. A análise das gônadas mostrou que 10 fêmeas têm 4-13 folículos vitelogênicos (média de 7.8 \pm 2.8 folículos), e duas fêmeas apresentam ovos nos ovidutos, uma com apenas um ovo e a outra com cinco ovos. O tamanho mínimo de maturidade estimado para as fêmeas de O. trigeminus na Caatinga é $400 \mathrm{~mm}$.
\end{abstract}

Palavras-chave: condição reprodutiva, dados merísticos, ecologia alimentar, Floresta Tropical Seca, Pseudoboini.

\section{Introduction}

The Caatinga Domain is a well-recognized ecological region of about $912,000 \mathrm{~km}^{2}$ in semiarid northeastern Brazil. It is the largest and most continuous expanse of seasonally dry tropical forest and woodland biome in the world (Queiroz et al. 2017). Ecological studies on snakes of the Caatinga are scarce, with several geographical sampling gaps (Vitt and Vangilder 1983, Mesquita et al. 2011, 2013). Many ecological studies of tropical snakes are based on field observations (e.g., Vitt and Vangilder 1983, Martins and Oliveira 1998, França et al. 2008). However, investigations conducted with specimens deposited in scientific collections may also provide a significant amount of reliable ecological data (Pizzato and Marques 2002, Gaiarsa et al. 2013, Reis et al. 2015).

Oxyrhopus trigeminus Duméril, Bibron and Duméril, 1854 is an oviparous, predominantly terrestrial snake, with a nocturnal-diurnal activity pattern (Vitt and Vangilder 1983, Alencar et al. 2012, Gaiarsa et al. 2013). The species ranges from Marajó Island in the state of Pará to the state of Rio de Janeiro-a distribution that includes much of the Cerrado, Caatinga, Atlantic Forest, and Amazon domains in Brazil (Peters and Orejas-Miranda 1970, Zaher and Caramaschi 1992, Guedes et al. 2014). Regional life-history data for $O$. trigeminus will contribute to an understanding of the patterns of ecological geographic variation of this widely distributed species (Alencar et al. 2012). In this study, we examined preserved specimens of $O$. trigeminus from several localities in the southern "Sertaneja" Depression and Northern "Sertaneja" Depression ecoregions of the Caatinga (sensu Velloso et al. 2002) to describe morphometry, diet composition, and reproductive aspects of females (clutch size, breeding period, and minimum size at maturity).

\section{Materials and Methods}

The 97 snakes examined were collected between 2008 and 2014 from the faunal rescue program conducted in the east and north axes of the São Francisco River Integration Project with the Northeast Watersheds (Projeto de Integração do Rio São Francisco com as Bacias Hidrográficas do Nordeste Setentrional-PISF). An extension of $477 \mathrm{~km}$ (eastern and northern 
axes of the PISF; Figure 1) was sampled during the process of vegetation removal due to the installation of the project, and Oxyrhopus trigeminus was collected by hand as individuals were sighted. The snakes originated from eight municipalities in the states of Ceará (Brejo Santo and Mauriti), Pernambuco (Cabrobó, Custódia, Floresta, Salgueiro and Sertânia), and Paraíba (São José de Piranhas; Figure 1). We used Zaher and Caramaschi (1992) to verify the identity of the snakes, which are preserved in $70 \%$ ethanol and deposited in the Coleção Herpetológica of the Museu de Fauna da Caatinga (MFCH), located at the Centro de Conservação e Manejo de Fauna da Caatinga
(CEMAFAUNA-CAATINGA), Universidade Federal do Vale do São Francisco in the municipality of Petrolina and state of Pernambuco in northeastern Brazil (vouchers: MFCH 2669-2753, 3367, 3401, 3409, 3456, $3480,3512,3560,3584,3603,3635,3637$, and 3647).

The following meristic data were recorded for each specimen: snout-vent length (SVL), tail length (TL), and head length (HL as measured from the tip of the snout to the posterior extremity of the quadrate-articular projection; Shine 1991); digital calipers were used for all measurements (to the nearest 0.01 $\mathrm{mm}$ ) of the snakes and their stomach contents.

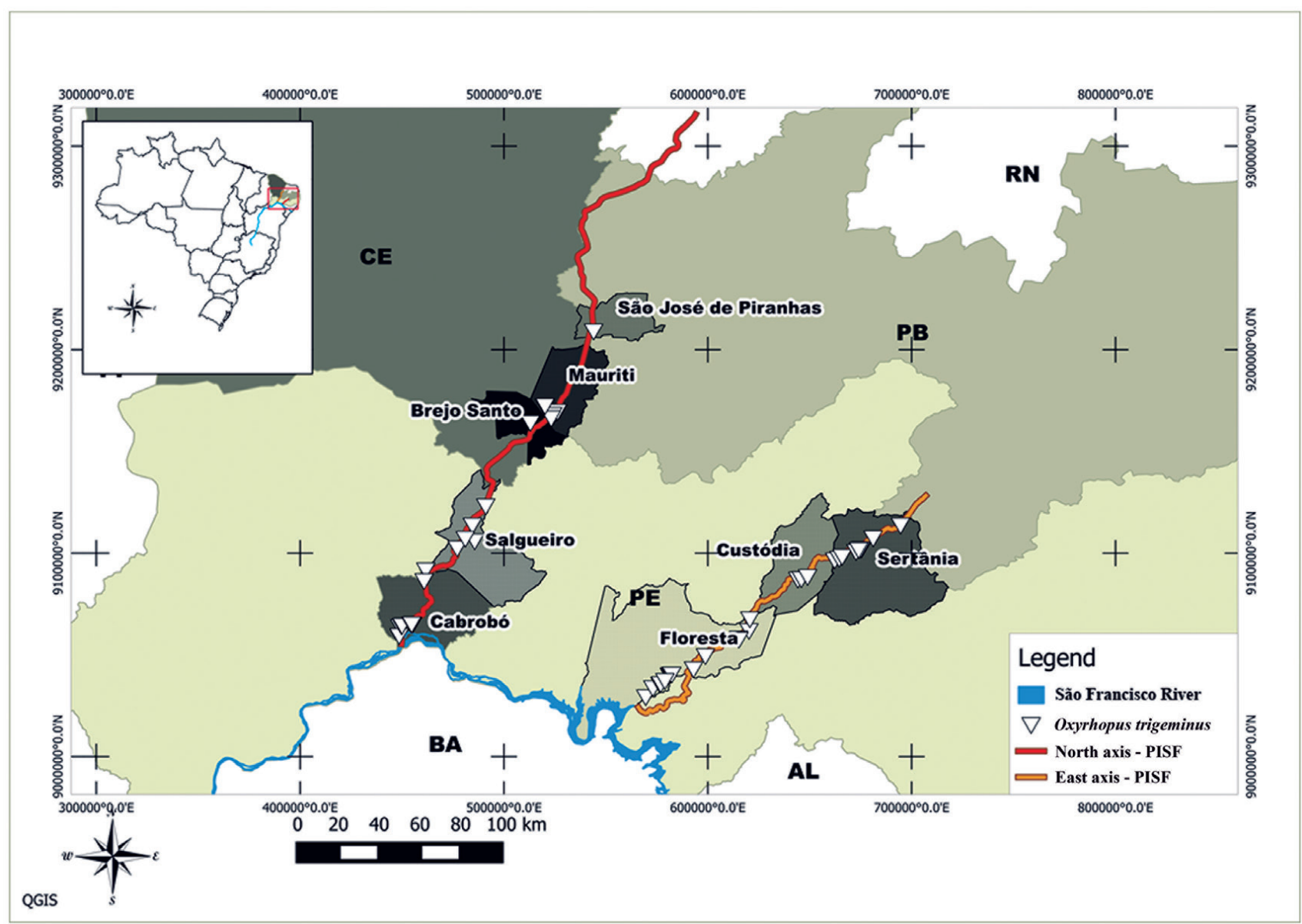

Figure 1. Distribution of Oxyrhopus trigeminus examined in this study. Individuals were collected along the north (red line) and east (orange line) axes of transposition channels of the Integration Project of the São Francisco River (PISF), northeastern Brazil. Legend to Brazilian states: AL, Alagoas; BA, Bahia; CE, Ceará; PB, Paraíba; PE, Pernambuco; RN, Rio Grande do Norte. 
After draining preservation fluids from the snakes, body mass (g) was measured with Pesola scales (to the nearest $0.1 \mathrm{~g}$ ).

To evaluate sexual dimorphism, we used an analysis of variance (ANOVA) for SVL, and an analysis of covariance (ANCOVA) for the other variables (TL, HL, body mass), with SVL as the covariate. Prior to performing these tests, we analyzed the data for normality and homogeneity of variances through Shapiro-Wilk and Levene's tests, respectively. Small juveniles (SVL $<225$ $\mathrm{mm}$ ) were excluded from the morphometric analyses because we could not determine the sex. Similarly, we excluded poorly preserved (e.g., dehydrated, mutilated) specimens.

A ventral incision was made in the snakes to remove the stomachs and examine the gonads (Alencar et al. 2012). We placed the stomachs in Petri dishes, and identified prey items at the lowest possible taxonomic level (usually species). The length and width of each prey item was recorded, and prey volume was estimated by the formula for a prolate spheroid: $V=(4 / 3) \pi$. (length/2).(width/2) $)^{2}$ (Dunham 1983). We calculated niche width for juveniles $(\mathrm{SVL}<225$ $\mathrm{mm}$ ), males, and females with Simpson's reciprocal index (Krebs 1999), in which values range from 1 (use of only 1 prey category) to $N$ (equal use of $N$ prey categories). Pianka's overlap index (Pianka 1973) was used to calculate similarities in diet composition of juveniles, males, and females, and the presence of sexual differences in prey volume was determined by Mann-Whitney's U-test (excluding prey items that were fragmented).
In females, we counted the number and measured the diameter of vitellogenic follicles and eggs in the oviducts (when present). Females were considered mature if they had enlarged follicles $(>10 \mathrm{~mm}$ ) or eggs in the oviduct (Pizzato and Marques 2002, Alencar et al. 2012). Because we had only a small sample of gravid females, we estimated clutch size based on number of vitellogenic follicles (Almeida-Santos et al. 2014) and tested the relationship between female SVL and clutch size with a linear regression.

All statistical tests were performed using IBM SPSS Statistics 20 for Windows, with a confidence level of $95 \%$. Descriptive statistics represent mean \pm standard deviation.

\section{Results}

Meristic data for 67 male and female Oxyrhopus trigeminus are presented in Table 1. Females are larger than males in SVL (ANOVA, $\left.F_{1,65}=10.261, p=0.002\right)$, but males have relatively larger heads (HL: ANCOVA, $F_{1,64}=$ 9.918, $p=0.002$; Figure 2A) and tails (TL: ANCOVA, $F_{1,64}=205.574, p<0.001$; Figure 2B). Males and females do not differ in body mass (ANCOVA, $F_{1,64}=0.316, p=0.576$ ).

Stomach contents were recovered from 23 of the 97 Oxyrhopus trigeminus specimens (7 males, 12 females, 4 juveniles); $76.3 \%$ of the snakes had empty stomachs. Each of two individuals (MFCH 2692, 2721) had two prey items in the stomach, but most (21) had only one prey item. Based on their orientation inside

Table 1. Meristic data for male and female Oxyrhopus trigeminus collected in the Brazilian Caatinga. SVL $=$ snoutvent length, $\mathrm{TL}=$ tail length, $\mathrm{HL}=$ head length, all in millimetres. Body mass in grams.

\begin{tabular}{lcc}
\hline & Males $(\mathbf{N}=\mathbf{2 5})$ & Females $(\mathbf{N}=\mathbf{4 2})$ \\
\hline SVL & $389.4 \pm 74.7(226-498)$ & $467.1 \pm 106.6(264-703)$ \\
TL & $98.8 \pm 20.7(51-128)$ & $93.4 \pm 21.7(48-148)$ \\
HL & $15.6 \pm 2.2(11.1-19.4)$ & $16.5 \pm 2.6(11.1-20.4)$ \\
Body mass & $29 \pm 15.3(6-62)$ & $41.6 \pm 20.1(8-90)$ \\
\hline
\end{tabular}



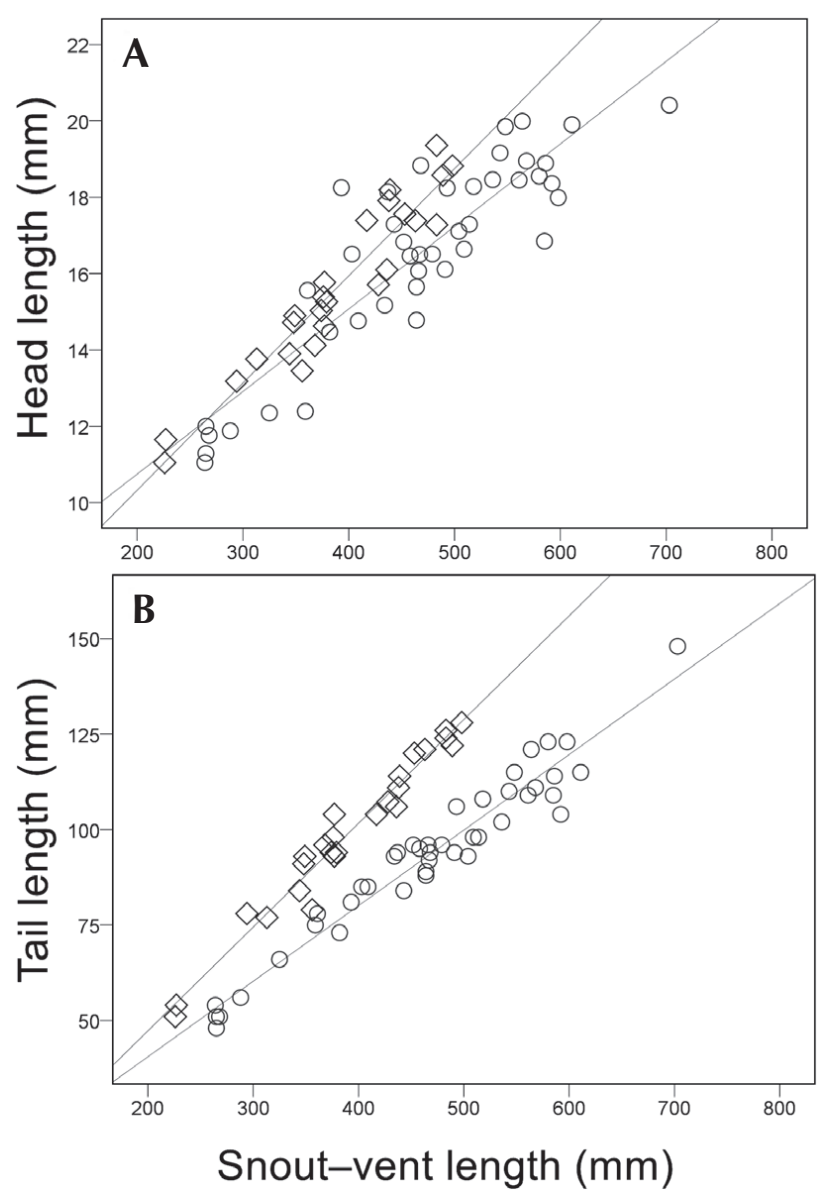

Figure 2. Relationship between snout-vent length and (A) head length and (B) tail length of Oxyrhopus trigeminus from the Brazilian Caatinga. Squares represent males $\left(\mathrm{SVL} \times \mathrm{HL}: \mathrm{R}^{2}=\right.$ $0.904, y=0.03 x+4.71 ; \mathrm{SVL} \times \mathrm{TL}: \mathrm{R}^{2}=$ $0.963, y=0.27 x-7.04)$ and circles represent females $\left(\mathrm{SVL} \times \mathrm{HL}: \mathrm{R}^{2}=0.792, \mathrm{y}=0.02 \mathrm{x}+\right.$ 6.43; SVL $\left.\times T L: R^{2}=0.943, y=0.20 x+0.93\right)$.

the stomachs, all 25 identified prey items (Table 2 ) had been ingested headfirst. The diet of $O$. trigeminus consists primarily of lizards (96\%, Table 2). However, the remnants of a mammal were found in one stomach (Table 2); analysis of the hair revealed that remains are those of a marsupial, the gray short-tailed opossum, Monodelphis domestica (Wagner, 1842). The average prey volume is $10,381.2 \pm 19,464.1$ $\mathrm{mm}^{3}$ with a range from $24.2 \mathrm{~mm}^{3}$ [one gymnophthalmid lizard, Vanzosaura multiscutata (Amaral, 1933)] to $74,333.2 \mathrm{~mm}^{3}$ [one tropidurid lizard, Tropidurus hispidus (Spix, 1825)]. Tropidurus hispidus is the most important prey species both in number and in volume (Table 2). Males and females do not differ in prey volume (Mann-Whitney, $\mathrm{U}=$ 23.0, $p=0.506$ ).

Juvenile Oxyrhopus trigeminus have the narrowest dietary niche width (2.000), consisting of only two prey species [a gymnophthalmid, $V$. multiscutata, and a skink, Brasiliscincus heathi (Schmidt and Inger, 1951)]. Males have a somewhat broader dietary niche (2.579) comprising four prey species [a gecko, Gymnodactylus geckoides (Spix, 1825); a teiid, Ameivula ocellifera (Spix, 1825); a tropidurid, Tropidurus hispidus; and the marsupial Monodelphis domestica]. Females have the widest dietary niche (3.769) that consists of six prey species [the lizards $V$. multiscutata, $G$. geckoides, B. heathi, Ameiva ameiva (Linnaeus, 1758), T. hispidus, and traces of an unidentified lizard]. Diet overlap is high between males and females $\left(\mathrm{O}_{j \mathrm{k}}=0.795\right)$, intermediate between females and juveniles $\left(\mathrm{O}_{\mathrm{jk}}=0.490\right)$, and absent between males and juveniles $\left(\mathrm{O}_{\mathrm{jk}}=0\right)$.

Examination of the gonads revealed that 10 female Oxyrhopus trigeminus have 4-13 vitellogenic follicles (mean: $7.8 \pm 2.8$ follicles). Two others have eggs in the oviduct; one has only one egg (33.0 mm long) and the other has five eggs, the largest of which is $32.4 \mathrm{~mm}$ long. There is a positive relationship between female SVL and the number of vitellogenic follicles $\left(\mathrm{R}^{2}\right.$ $\left.=0.486, F_{1,8}=7.571, p=0.025\right)$. Given the small sample size of gravid females $(N=2)$, we could not test the relationship between SVL and number of eggs in the oviducts. Vitellogenic follicles are present in snakes collected in January-March, June-August, and December, whereas gravid females were collected in March and July (Figure 3). We recorded vitellogenic follicles in females with SVL $>400 \mathrm{~mm}$, and eggs in females with SVL $>600 \mathrm{~mm}$. 
Table 2. Diet composition of Oxyrhopus trigeminus $(N=97)$ in the Brazilian Caatinga. $N=$ number of prey items, $\mathrm{NC}=$ numeric contribution of each prey category, $\mathrm{V}=$ volume, $\mathrm{VC}=$ volumetric contribution of each prey category. Asterisks $(*)$ indicate prey items too fragmented to estimate volume.

\begin{tabular}{|c|c|c|c|c|c|}
\hline Prey species & Family & $N$ & NC $(\%)$ & $V\left(\mathbf{m m}^{3}\right)$ & VC (\%) \\
\hline Vanzosaura multiscutata & Gymnophthalmidae & 5 & 20 & 2291.2 & 1.0 \\
\hline Gymnodactylus geckoides & Phyllodactylidae & 2 & 8 & 3136.0 & 1.3 \\
\hline Brasiliscincus heathi & Mabuyidae & 4 & 16 & 7880.3 & 3.3 \\
\hline Ameiva ameiva & Teiidae & 1 & 4 & 5586.4 & 2.3 \\
\hline Ameivula ocellifera & Teiidae & 1 & 4 & 7311.4 & 3.1 \\
\hline Tropidurus hispidus & Tropiduridae & 10 & 40 & $212,563.3$ & 89.0 \\
\hline Undetermined lizard & - & 1 & 4 & $*$ & $*$ \\
\hline Monodelphis domestica & Didelphidae & 1 & 4 & $*$ & * \\
\hline Total & & 25 & 100 & $238,768.6$ & 100 \\
\hline
\end{tabular}

\section{Discussion}

The sexual dimorphism in body size (SVL), with females being larger than males, also occurs in other pseudoboine snake species (Pizzato and Marques 2002; Alencar et al. 2012). Kaufman and Gibbons (1975) and Pizzatto (2005) suggested that larger-bodied females may carry more eggs. Males have larger tails than females to accommodate the hemipenes and their associated muscles (King 1989, Bonnet et al. 1998, Shine et al. 1999). The sexual dimorphism in head size documented in O. trigeminus is not a common trend in snakes (Shine 1991). It is possible that selective forces may have favored males with larger heads of competing for access to reproductive females, as has been proposed for lizards (Anderson and Vitt 1990). However, males of most snake species do not fight each other (Carpenter and Ferguson 1977, Shine 1991). An alternate explanation for head-size dimorphism in snakes implicates ecological forces that allow ingestion of larger prey because snakes are gape-limited predators (Shine 1991). Thus, despite being smaller than females, natural selection may have favored larger heads in male $O$. trigeminus to allow ingestion of large prey.

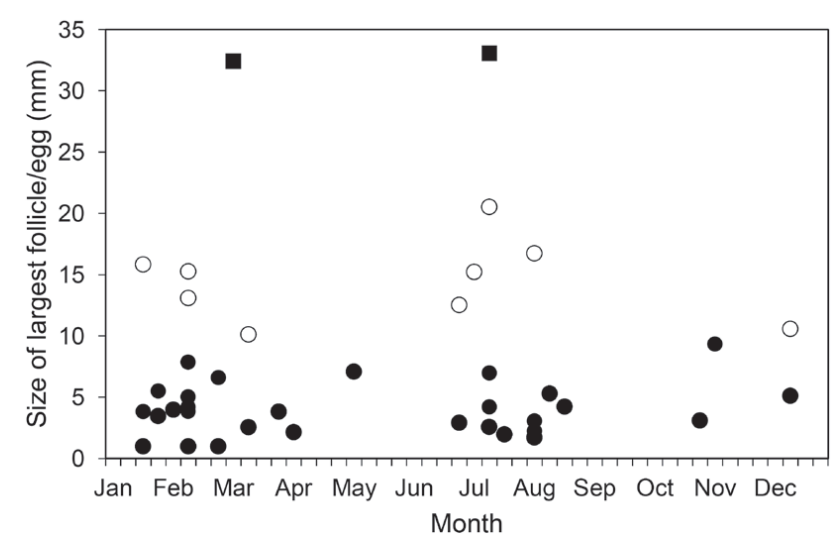

Figure 3. Seasonal variation in the diameter of the largest ovarian follicle or egg of Oxyrhopus trigeminus in the Brazilian Caatinga. Black circles: females containing immature follicles $(<10 \mathrm{~mm})$. White circles: females containing vitellogenic follicles (> $10 \mathrm{~mm}$ ). Black squares: females containing eggs in the oviducts.

Our dietary data, however, do not support this hypothesis.

The narrower niche width of juvenile $O$. trigeminus likely is related to gape limitations that constrain them to consume small prey, while adults can target a wider range of prey sizes (Costa et al. 2008). The lizards Ameiva ameiva and Tropidurus hispidus also occur in the diet of 
O. trigeminus from an Atlantic Forest site in the state of Minas Gerais (Alencar et al. 2012). In that study, rodents $(37.5 \%)$ and lizards $(37.5 \%)$ are predominant numerically, followed by birds $(12.5 \%)$ and marsupials (12.5\%); empty stomachs accounted for $70.8 \%$. In the Cerrado of central Brazil, in Distrito Federal, the diet of $O$. trigeminus is composed predominantly of mammals (71.4\%), followed by lizards (29.6\%); empty stomachs accounted for $41.6 \%$ (França et al. 2008). Finally, in a transition area between Caatinga, Cerrado, and Atlantic Forest domains in the state of Minas Gerais, the diet of $O$. trigeminus is composed of lizards (46.7\%), rodents (33.3\%), and birds (20\%), with empty stomachs accounting for $74.6 \%$ (Alencar et al. 2012). Comparison of the results of these studies with ours indicates that the diet of $O$. trigeminus varies geographically, with Caatinga populations consuming more lizards $(96 \%)$ than any other prey category than populations in the Atlantic Forest and Cerrado. Vitt and Vangilder (1983) also found mainly lizards $(85.7 \%)$ in the diet of $O$. trigeminus in a Caatinga area of the state of Pernambuco.

Alencar et al. (2012) reported an estimated clutch size of $7.5 \pm 2.8$ (range: 1-11, eggs and follicles together) for a population of Oxyrhopus trigeminus from the state of Minas Gerais, southeastern Brazil; this is consistent with our results. Vitt and Vangilder (1983) reported an estimated clutch size of 6.5 (range: 6 or 7 vitellogenic follicles) for a Caatinga population, but their sample consisted of only two reproductive females.

As found in previous studies in other Brazilian ecosystems (Alencar et al. 2012), we observed female $O$. trigeminus to have vitellogenic follicles in several months of the year; however, our sample of gravid females was too small to estimate the reproductive period of $O$. trigeminus throughout the year in the Caatinga. With respect to minimum size at maturity, our finding for the Caatinga region of $400 \mathrm{~mm}$ SVL is less than the minimum size at maturity previously reported (536 mm SVL; Gaiarsa et al. 2013). The duration of the reproductive period should be further investigated.

\section{Acknowledgments}

We thank the Instituto Brasileiro do Meio Ambiente e Recursos Naturais Renováveis (IBAMA) for the collection permits (number 042/2007, 125.r/2010 e 95/2012). Special thanks are extended to Leandro da Silva Oliveira and Carla Bantel of the Centro de Conservação e Manejo de Fauna da Caatinga for identification of the marsupial, and to two anonymous referees for manuscript revisions. RDFC received a research grant from the Conselho Nacional de Desenvolvimento Científico e TecnológicoCNPq (Process 139425/2013-6).

\section{References}

Alencar, L. R. V., C. A. B. Galdino, and L. B. Nascimento. 2012. Life history aspects of Oxyrhopus trigeminus (Serpentes: Dipsadidae) from two sites in southeastern Brazil. Journal of Herpetology 46: 9-13.

Almeida-Santos, S. M., H. B. Braz, L. C. Santos, L. R. Sueiro, V. A. Barros, C. A. Rojas, and K. N. Kasperoviczus. 2014. Biologia reprodutiva de serpentes: recomendações para a coleta e análise de dados. Herpetologia Brasileira 3: $14-24$.

Anderson, R. A. and L. J. Vitt. 1990. Sexual selection versus alternative causes of sexual dimorphism in teiid lizards. Oecologia 84: 145-157.

Bonnet, X., R. Shine, G. Naulleau, and M. Vacher-Vallas. 1998. Sexual dimorphism in snakes: different reproductive roles favour different body plans. Proceedings of the Royal Society B, Biological Sciences 265: 179-183.

Carpenter, C. C. and G. W. Ferguson. 1977. Variation and evolution of stereotyped behavior in reptiles. Pp. 335554 in C. Gans and D. W. Tinkle (eds.), Biology of the Reptilia, Ecology and Behaviour A. Volume 7. London. Academic Press Inc.

Costa, G. C., L. J. Vitt, E. R. Pianka, D. O. Mesquita, and G. R. Colli. 2008. Optimal foraging constrains macroecological patterns: body size and dietary niche breadth in lizards. Global Ecology and Biogeography 17: 670-677.

Dunham, A. E. 1983. Realized niche overlap, resource abundance, and intensity of interspecific competition. Pp. 261-280 in R. B. Huey, E. R. Pianka, and T. W. Schoener (eds), Lizard Ecology: Studies of a Model Organism. Cambridge. Harvard University Press. 
França, F. G. R., D. O. Mesquita, C. C. Nogueira, and A. F. B. Araújo. 2008. Phylogeny and ecology determine morphological structure in a snake assemblage in the central Brazilian Cerrado. Copeia 2008: 23-38.

Gaiarsa, M. P., L. R. V. Alencar, and M. Martins. 2013. Natural history of pseudoboine snakes. Papéis Avulsos de Zoologia 53: 261-283.

Guedes, T. B., C. Nogueira, and O. A. V. Marques. 2014. Diversity, natural history, and geographic distribution of snakes in the Caatinga, Northeastern Brazil. Zootaxa 3863: 1-93.

Kaufman, G. A. and J. W. Gibbons. 1975. Weight length relationships in thirteen species of snakes in the southeastern United States. Herpetologica 31: 31-37.

King, R. 1989. Sexual dimorphism in snakes tail length: sexual selection, natural selection, or morphological constraint? Biological Journal of the Linnean Society 38: 133-154.

Krebs, C. J. 1999. Ecological Methodology. $2^{\text {nd }}$ Edition. Menlo Park. Addison Wesley Longman. 620 pp.

Martins, M. and M. E. Oliveira. 1998. Natural history of snakes in Forests of the Manaus Region, Central Amazonia, Brazil. Herpetological Natural History 6: $78-150$.

Mesquita, P. C. M. D., D. M. Borges-Nojosa, D. C. Passos, and C. H. Bezerra. 2011. Ecology of Philodryas nattereri in the Brazilian semi-arid region. Herpetological Journal 21: $193-198$.

Mesquita, P. C. M. D., D. C. Passos, D. M. Borges-Nojosa, and S. Z. Cechin. 2013. Ecologia e história natural das serpentes de uma área de Caatinga no nordeste brasileiro. Papéis Avulsos de Zoologia 53: 99-113.

Peters, J. A. and B. Orejas-Miranda. 1970. Catalogue of the Neotropical Squamata, Part I. Snakes. Washington. Smithsonian Institution Press. 347 pp.

Pianka, E. R. 1973. The structure of lizard communities. Annual Review of Ecology, Evolution, and Systematics 4: 53-74.
Pizzatto, L. 2005. Body size, reproductive biology and abundance of the rare pseudoboini snakes genera Clelia and Boiruna (Serpentes, Colubridae) in Brazil. Phyllomedusa 4: 111-122.

Pizzato, L. and O. A. V. Marques. 2002. Reprodutive biology of the false coral snake Oxyrhopus guibei from southeastern Brazil. Amphibia-Reptilia 23: 495-504.

Queiroz, L. P., D. Cardoso, M. F. Fernandes, and M. F. Moro. 2017. Diversity and evolution of flowering plants of the Caatinga domain. Pp. 23-63 in J. M. C. Silva, I. R. Leal, and M. Tabarelli (eds), Caatinga, the Largest Tropical Dry Forest Region in South America. Cham. Springer.

Reis, P. M. A. G., R. D. F. Coelho, L. M. N. Menezes, and L. B. Ribeiro. 2015. Contribution to the reproductive biology of Bothrops erythromelas (Squamata: Viperidae) in the semiarid region of Brazil. Herpetological Review 46: $327-331$.

Shine, R. 1991. Intersexual dietary divergence and the evolution of sexual dimorphism in snakes. American Naturalist 138: 103-122.

Shine, R., M. M. Olsson, I. T. Moore, M. P. LeMaster, and R. T. Mason. 1999. Why do male snakes have longer tails than females? Proceedings of the Royal Society of London 266: 2147-2151.

Velloso, A. L., E. V. S. B. Sampaio, and F. G. C. Pareyn (eds.). 2002. Ecorregiões: Propostas para o Bioma Caatinga. Recife. Instituto de Conservação Ambiental The Nature Conservancy do Brasil. 76 pp.

Vitt, L. J. and L. D. Vangilder. 1983. Ecology of a snake community in Northeastern Brazil. Amphibia-Reptilia 4: 273-296.

Zaher, H. and U. Caramaschi. 1992. Sur le statut taxinomique d'Oxyrhopus trigeminus et $O$. guibei. Bulletin $d u$ Muséum National d'Histoire Naturelle 14: 805-827.

Editor: Jaime Bertoluci 